\title{
Dimeric Phenazinothiadiazole Acceptors in Bulk Heterojunction Solar Cells
}

\author{
Lukas Ahrens ${ }^{a}$ \\ Yvonne J. Hofstetter ${ }^{b}$ (D) \\ Baris Celik ${ }^{a}$ \\ Julian F. Butscher ${ }^{b}$ (D) \\ Frank Rominger $^{a}$ \\ Jan Freudenberg ${ }^{* a}$ (iD \\ Yana Vaynzof*b (D) \\ Uwe H. F. Bunz*a (D) \\ a Organisch-Chemisches Institut, Ruprecht-Karls-Universität Heidelberg, \\ Im Neuenheimer Feld 270, 69120 Heidelberg, Germany \\ ${ }^{\mathrm{b}}$ Institut für Angewandte Physik, Technische Universität Dresden, Nöthnitzer Straße \\ 61, 01187 Dresden, Germany \\ freudenberg@oci.uni-heidelberg.de; yana.vaynzof@tu-dresden.de; \\ uwe.bunz@oci.uni-heidelberg.de
}

Dedicated to Professor Peter Bäuerle on the occasion of his 65th birthday.

Received: 15.01.2021

Accepted after revision: 16.02 .2021

DOI: 10.1055/s-0041-1726459; Art ID: om-21-0007sc

License terms: (c)

(c) 2021. The Author(s). This is an open access article published by Thieme under the terms of the Creative Commons Attribution-NonDerivative-NonCommercial License, permitting copying and reproduction so long as the original work is given appropriate credit. Contents may not be used for commercial purposes, or adapted, remixed, transformed or built upon. (https://creativecommons.org/licenses/by-nc-nd/4.0/)

Abstract Two covalently linked triisopropylsilyl-ethynylated phenazinothiadiazoles were prepared through condensation of a spirocyclic and a bicyclic tetraketone with a 5,6-diaminobenzothiadiazole. The spirobisindene- and the ethanoanthracene-based linkers render the electron acceptors amorphous in thin films. The optoelectronic properties of the non-conjugated dimers are indistinguishable from that of the crystalline monomer. Bulk heterojunction solar cells were prepared with power conversion efficiencies peaking at $1.6 \%$. The choice of linker neither influenced optical and electrochemical properties nor device performance.

Key words arenes, condensation, electron acceptors, non-fullerene acceptors, organic electronics, organic solar cells

\section{Introduction}

Tailor-made $\mathrm{N}$-heteroarenes ${ }^{1}$ are electron-deficient semiconductors with applications in organic field-effect transistors, ${ }^{2}$ organic light-emitting diodes ${ }^{3}$ and bulk heterojunction (BHJ) solar cells. ${ }^{4}$ Negative charges are stabilized in their radical anions; ${ }^{5}$ these are the charge-transporting species in thin-film transistors. ${ }^{6} \mathrm{~N}$-Heteroarenes are attractive electron acceptors for organic photovoltaics (OPVs). The hydrocarbon analogues, ${ }^{7}$ electron donors, cannot be used with fullerene acceptors due to Diels-Alder adduct formation; $^{8}$ azaacenes and azaarenes, however, can be combined

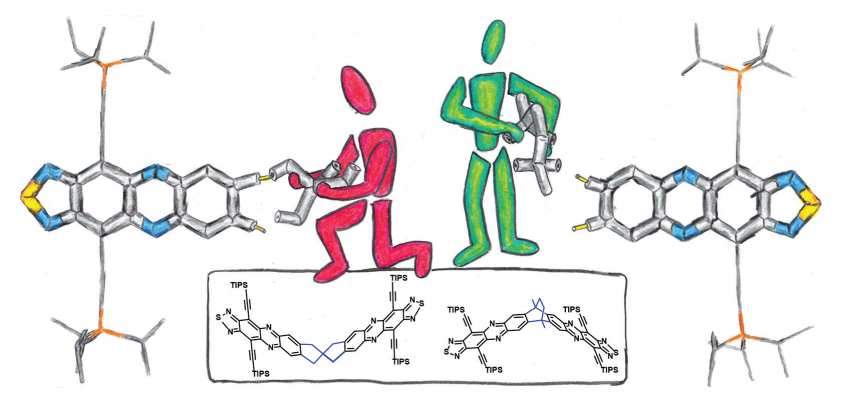

with donors such as PTB7, ${ }^{4}$ P3HT and PCPDTBT ${ }^{4 a}$ Triisopropylsilyl (TIPS)-ethynylated (hetero)acenes and (hetero)arenes display a strong tendency to crystallize, ${ }^{4,9}$ and are therefore problematic in $\mathrm{BHJ}$ cells as phase segregation instead of $\mathrm{BHJ}$ formation occurs in thin-film blends. ${ }^{4 c}$

To control aggregation and morphology in bulk or mixtures, azaarenes are equipped with morphologydominating substituents such as iptycenes ${ }^{4 a}$ (e.g. A, Figure 1 ) or they are oligomerized; ${ }^{4 \mathrm{~b}, 4 \mathrm{~d}, 10}$ this improves photovoltaic performance. The resulting amorphous species balance acceptor properties, charge transport and percolation pathways in thin films. They are also quite soluble and processable.
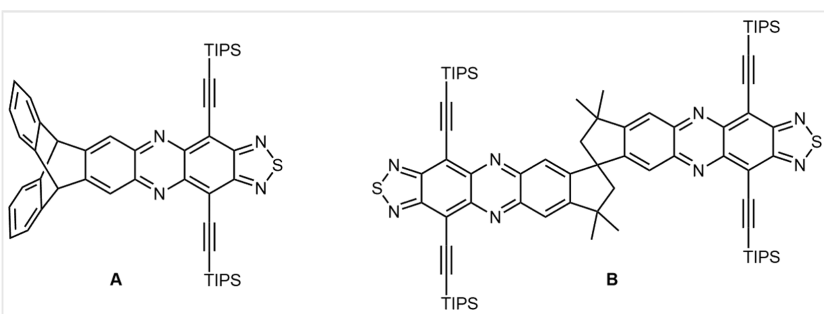

Figure 1 Selected acenothiadiazoles used as acceptor materials for $\mathrm{BH}$ solar cells. ${ }^{4 a 4 b}$

Others and we investigated spirobridged (hetero)acenes and acenothiadiazoles for intramolecular singlet fission ${ }^{11}$ and photovoltaics (e.g. B, Figure 1$){ }^{4 b}$ This $1,1^{\prime}$-spiro linkage was popularized by McKeown ${ }^{12 \mathrm{a} 12 \mathrm{~b}}$ and others ${ }^{12 \mathrm{c} 12 \mathrm{~d}}$ in polymers of intrinsic microporosity. ${ }^{12 e}$

Thiadiazoles performed better than tetra- and diazapentacenes in solar cells, but the effect of the linker was not clear. Herein, we study phenazinothiadiazoles, connected via two different linkers. ${ }^{12,13}$ We compare their optoelectronic properties and OPV performance to those of 

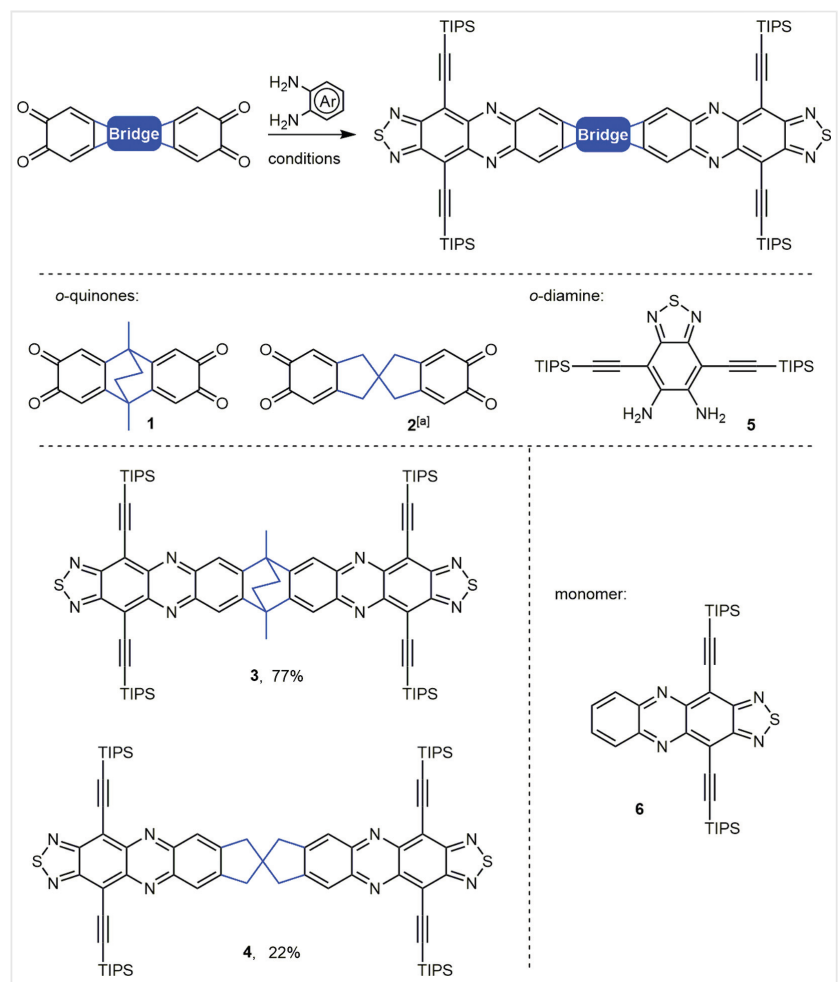

Scheme $\mathbf{1}$ Synthesis of dimers $\mathbf{3}$ and $\mathbf{4}$. $^{\mathrm{a}} \mathbf{2}$ was generated in situ from the tetraol and immediately used (see $\mathrm{SI}$ for details). Conditions: $\mathrm{CHCl}_{3}$, $\mathrm{HOAc}, 50^{\circ} \mathrm{C}, 15 \mathrm{~h}$.

thiadiazole $\mathbf{6}$ and $\mathbf{B}$ to study the role of the linker. In heteroarene dimers, the linker impacts bulk crystallinity.

\section{Results and Discussion}

2,5-Hexanedione reacts with catechol, and subsequent $\mathrm{NaIO}_{4}$ oxidation gives ethanoanthracenetetraone $\mathbf{1}$. Spirobisindenetetraone $\mathbf{2}$ is obtained after oxidation of its tetraol precursor, ${ }^{13}$ but decomposes within $1 \mathrm{~d}$. Its surprising reactivity might be attributed to better steric accessibility of 2 when compared to $\mathbf{1}$ and the precursor quinone for $\mathbf{B}$ - both stable under ambient conditions. Hence, $\mathbf{2}$ was used without purification. Condensation ${ }^{14}$ of quinones $\mathbf{1}$ and $\mathbf{2}$ with diamine 5 furnishes the target dimers $\mathbf{3}$ (77\% yield) ${ }^{15}$ and $\mathbf{4}$ $(22 \% \text { yield })^{16}$ as greenish-blue amorphous solids (Scheme 1 ). We ascribe the lower yield of $\mathbf{4}$ to the poorer solubility and purity as well as higher reactivity of quinone 2 compared to 1 .

Compared to the monomer $6\left(\lambda_{\max }=642 \mathrm{~nm}\right)$, the absorption maxima of $3\left(\lambda_{\max }=640 \mathrm{~nm}\right)$ and $4\left(\lambda_{\max }\right.$ $=636 \mathrm{~nm}$ ) are slightly blue-shifted by $2 / 0.01$ and $6 /$ $0.02 \mathrm{~nm} / \mathrm{eV}$ [see Figure 2 for photographs and Figure 3 (top) and Table 1 for spectra and spectral data]. The extinction coefficient of the chromophores $\mathbf{3}$ and $\mathbf{4}$ are twice as high as that of $\mathbf{6}$. In thin films, spun-cast from chloroform,
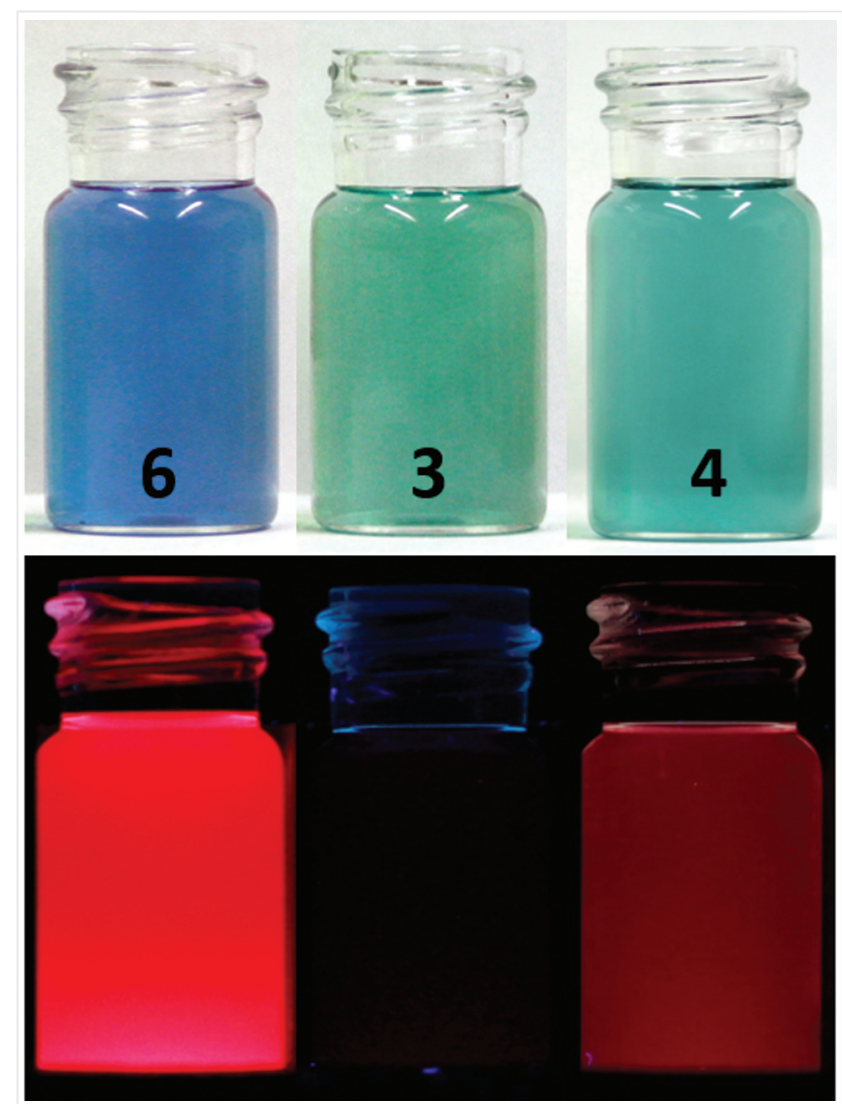

Figure 2 Photographs of monomer 6 (left), dimers 3 (middle) and $\mathbf{4}$ (right) under daylight (top) and UV light with excitation at $365 \mathrm{~nm}$ (bottom) in $n$-hexane.

the absorption features are narrowed compared to that of monomer $\mathbf{6}$ and resemble the spectra in solution, suggesting less intermolecular interactions and $\pi$-stacking, or reduced domain boundary scattering (amorphous film) as evidenced by the polarization micrographs (Figure 3, bottom). In contrast, thin films of the monomer $\mathbf{6}$ are crystalline.

The normalized absorption spectra of the dimers $\mathbf{3}$ and $\mathbf{4}$ are indistinguishable, but only $\mathbf{4}$ is faintly fluorescent (quantum yield $=2 \%$ ). In $\mathbf{3}$ the chromophores are closer together than in spiro linked dimer 4; also the geometry and rigidity differ (Figure 4, top). Density functional theory geometry optimizations of 3 and $\mathbf{4}$ furnish reduced $(3: 4.53 \AA$ ) and enlarged (4: $6.59 \AA$ ) closest distances of the acenothiadiazoles (center points of closest aromatic rings) compared to B $\left(5.08 \AA\right.$ ). The homodimer $\mathbf{3}$ is $C_{2 \mathrm{v}}$-symmetric, $\mathbf{4}$ (and $\mathbf{B}$ ) are of $\mathrm{C}_{2}$ symmetry, due to the cyclopentylene moieties of the dimer 4 preferably adopting an envelope conformation.

Recently, Mastalerz et al. disclosed homoaromaticity of triptycene-based chromophores, ${ }^{17}$ expressed as individually observed reduction waves of each arm under cyclic voltammetry conditions - not observed for the dimers 3 or $\mathbf{4}$. The first reduction potentials are $\mathbf{6}(-0.85 \mathrm{~V})>\mathbf{3}(-0.90 \mathrm{~V})>\mathbf{4}$ 

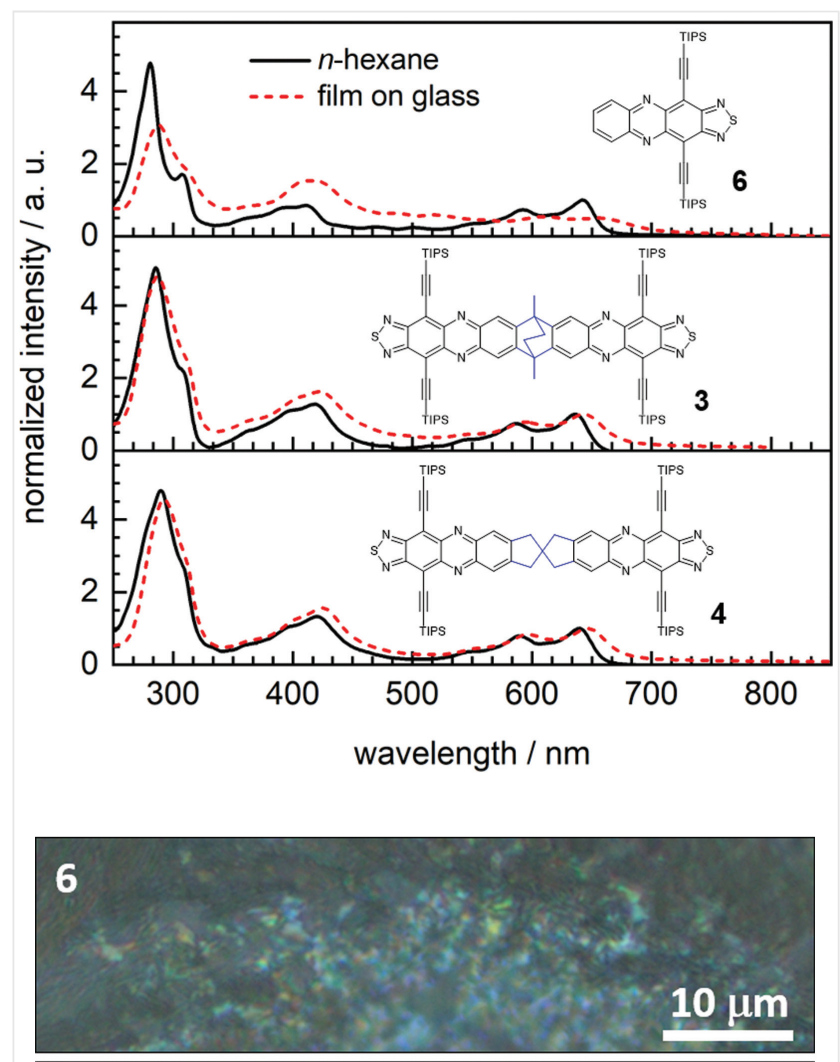

3

\section{$10 \mu \mathrm{m}$}

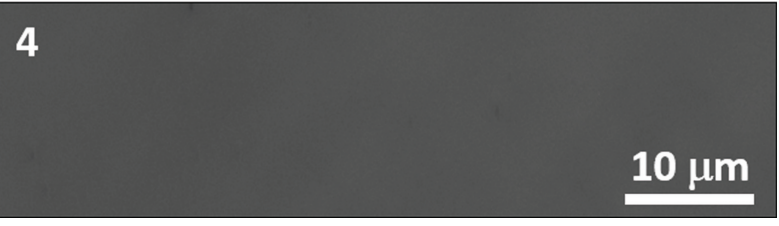

Figure 3 Top: Normalized absorption spectra of 3, 4 and $\mathbf{6}$ in $n$-hexane (black, dilute solution) and spun-cast thin-films on glass (red, from chloroform, $c=10 \mathrm{mg} \mathrm{mL}^{-1}$ ). Bottom: Microscopic images of spin-coated thin films of $\mathbf{3}$ (middle), $\mathbf{4}$ (bottom) and $\mathbf{6}$ (top) on glass (10 $\mathrm{mg} \mathrm{mL}^{-1}$, chloroform) under crossed polarizers.

$\left(-0.92 \mathrm{~V}\right.$, all vs. $\left.\mathrm{Fc} / \mathrm{Fc}^{+}\right)$, due to the electron-releasing effect of the linkers, comparable to those of two alkyl groups.

Dimer $\mathbf{4}$ did not crystallize, while $\mathbf{3}$ gave specimen suitable for X-ray crystal structure analysis - note that various attempts and variation of crystallization conditions were necessary to obtain viable crystals. The often-observed S-N interactions are absent in this structure. ${ }^{18}$ Compound $\mathbf{3}$ packs in one-dimensional stacks. Molecules of each stack face the same direction. Adjacent stacks are oriented in opposite directions. The TIPS-ethynyl substituents protrude a)

b)
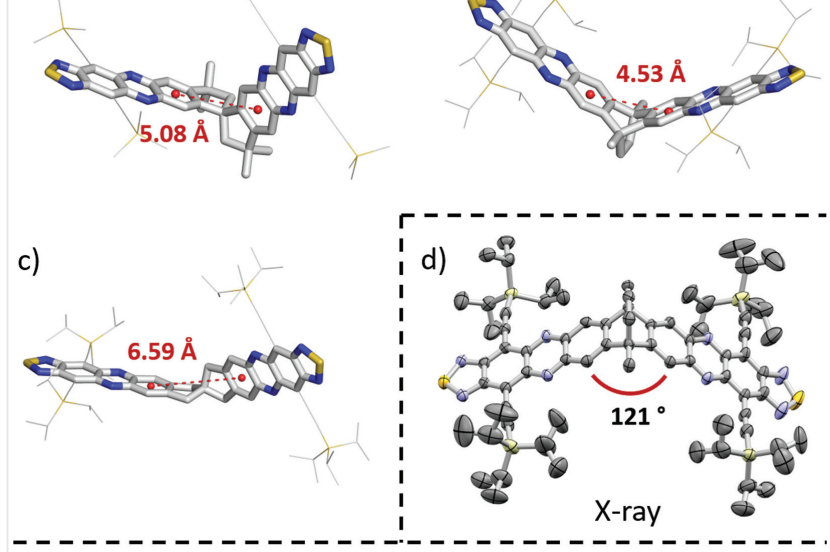

e)

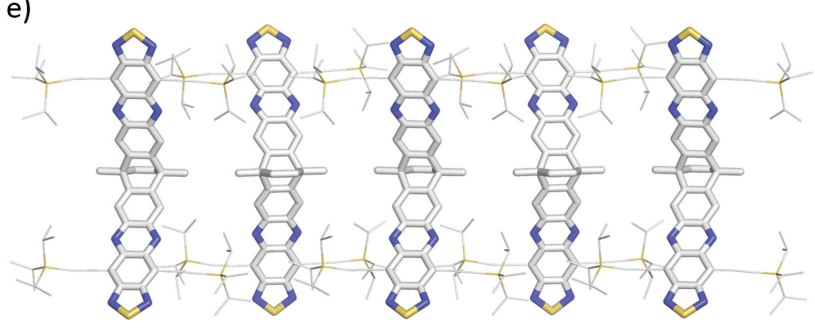

Figure 4 DFT-optimized geometries of B (a), 3 (b) and 4 (c) (B3LYP/ def2-SVP // B3LYP/def2-TZVP) and calculated distance between center points of closest aromatic rings. ${ }^{19}$ Solid-state structure of $\mathbf{3}$ (d) and its crystal packing (e). The angle between the azaarene subunits is approximately $121^{\circ}$ (angle estimated from best-fit planes of closest aromatic rings; ellipsoids set to $50 \%$ probability level).

into the neighboring stacks and prevent intermolecular $\pi-\pi$ interactions. One of 3's phenazinothiadiazole arms is slightly bent due to packing effects.

To investigate the feasibility of the phenazinothiadiazole dimers 3, 4 and $\mathbf{B}$ as electron acceptors in OPV devices, they were mixed with the donor polymer poly $(\{4,8$-bis[ $[2-$ ethylhexyl)oxy]benzo[1,2-b:4,5- $\left.b^{\prime}\right]$ dithiophene-2,6-diyl $\}$ \{3-fluoro-2-[(2-ethylhexyl)carbonyl]thieno[3,4-b]thiophenediyl\}) (PTB7) to form BHJ solar cells. ${ }^{20}$ A schematic of the solar-cell architecture and the chemical structures of the donor and acceptors are shown in Figure $5 a$ and b. Figure $5 c$ shows the external quantum efficiency (EQE) of the resultant OPV devices. Since PTB7 only weakly absorbs below $500 \mathrm{~nm}$, the EQE features in this spectral range can be attributed to the acceptors, in agreement with their absorption (Figure 3, top), demonstrating their contribution to the generation of photocurrent. Figure $5 \mathrm{~d}$ displays the current density-voltage characteristics of the best devices and Table 2 summarizes the average and highest achieved OPV performances. Overall, the three types of solar cells show similar performance. The choice of linker of the dimers has no significant influence on the OPV performance. As expected from the EQE spectra, OPVs with 
Table 1 Optical, electrochemical, and calculated (gas-phase) properties of phenazinothiadiazole dimers 3, 4, and their consanguine monomeric counterpart 6 in solution ( $n$-hexane).

\begin{tabular}{|c|c|c|c|c|c|c|c|c|}
\hline Cmpd & $\lambda_{\max }$ abs $[\mathrm{nm}]$ & 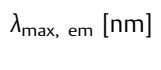 & $\varepsilon^{\mathrm{a}}\left[\mathrm{x} 10^{4} \mathrm{M}^{-1} \mathrm{~cm}^{-1}\right]$ & $\Phi$ & $E^{(0 /-)}[\mathrm{V}]^{\mathrm{c}}$ & $\begin{array}{l}\mathrm{IP} / \mathrm{HOMO}[\mathrm{eV}]^{\mathrm{d}} \\
\text { meas/calcd }\end{array}$ & $\begin{array}{l}\text { EA/LUMO }[\mathrm{eV}]^{\mathrm{f}} \\
\text { meas/calcd }\end{array}$ & $\begin{array}{l}\text { Gap }[\mathrm{eV}]^{\mathrm{g}} \\
\text { meas/calcd }\end{array}$ \\
\hline 6 & 642 & 651 & 5.87 & 0.46 & -0.85 & $-5.83 /-5.76$ & $-3.97 \mid-3.77$ & $1.86 / 1.99$ \\
\hline 3 & 640 & 647 & 13.6 & $-{ }^{\mathrm{b}}$ & -0.90 & $-6.06 /-5.72$ & $-4.20 /-3.79$ & $1.86 / 1.93$ \\
\hline 4 & 636 & 646 & 13.5 & 0.02 & -0.92 & $-6.06 /-5.73$ & $-4.18 /-3.72$ & $1.88 / 2.00$ \\
\hline
\end{tabular}

at $\lambda_{\text {max, abs. }}$

${ }^{\mathrm{b}}$ Non-emissive.

${ }^{\mathrm{C}}$ First reduction potentials from cyclic voltammetry $(\mathrm{CV})$ in $\mathrm{DCM}$ at room temperature with $\mathrm{Bu}_{4} \mathrm{NPF}_{6}$ as the electrolyte against Fc/Fc + as an internal standard $(-5.10 \mathrm{eV})$ at $0.2 \mathrm{Vs}^{-1}$

$\mathrm{d}_{\mathrm{IP}}=E A_{\text {meas }}-$ gap meas.

eObtained from DFT calculations (Gaussian 16: geometry optimization: B3LYP/def2-SVP// B3LYP/def2-TZVP; FMO calculations: B3LYP/def2-TZVP; TMS groups were used instead of TIPS). ${ }^{20}$

${ }^{\mathrm{f}} \mathrm{EA}$ meas $=-\mathrm{e}\left(5.1 \mathrm{~V}+E^{(0 /-)}\right){ }^{21}$

${ }^{\mathrm{g} G a p}$ meas calculated from $\lambda_{\text {onset }}$ in $n$-hexane.

a)

c)

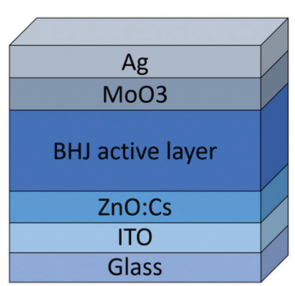

d)
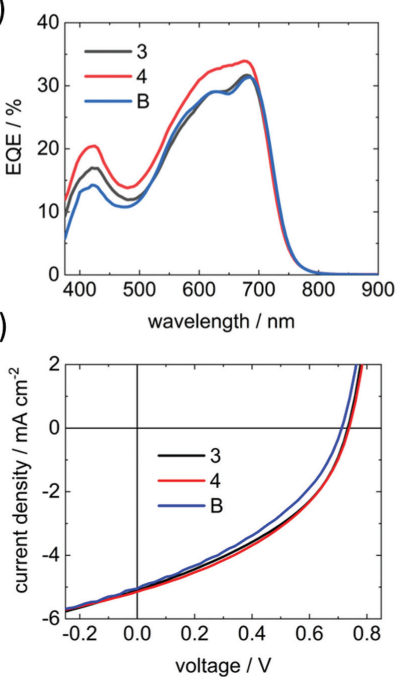

Figure 5 (a) Schematic of the OPV device architecture, (b) chemica structures of the materials used as the $\mathrm{BHJ}$ active layer, (c) external quantum efficiency and (d) current density-voltage characteristics of the best OPVs.

compound 4 exhibit the highest short-circuit current on average. The open-circuit voltage consistently reaches values of about $0.7 \mathrm{~V}$ for all OPVs which is related to the similarity in the acceptor LUMO positions (see Table 1 and Reference $4 \mathrm{~b}$ ). In all three cases, the fill factors are low and might be the result of unfavorable active layer morphologies. Lastly, it should be noted that the solar cell fabrication parameters have not been extensively optimized. However,
Table 2 Photovoltaic parameters of the OPVs utilizing compounds 3, 4, and $\mathbf{B}$ as acceptors and PTB7 as donor. The highest achieved values are given in brackets representing the $J-V$ curves shown in Figure $5 \mathrm{~d}$.

\begin{tabular}{lllll}
\hline Cmpd & $V_{\text {OC }}[\mathrm{V}]$ & $J_{\mathrm{SC}}\left[\mathrm{mA} \mathrm{cm} \mathrm{cm}^{-2}\right]$ & FF [\%] & PCE [\%] \\
\hline $\mathbf{3}$ & $0.73 \pm 0.01$ & $-4.62 \pm 0.30$ & $38.44 \pm 2.18$ & $1.29 \pm 0.15$ \\
& $(0.73)$ & $(-5.10)$ & $(40.56)$ & $(1.52)$ \\
$\mathbf{4}$ & $0.70 \pm 0.02$ & $-5.10 \pm 0.07$ & $38.56 \pm 1.89$ & $1.39 \pm 0.10$ \\
& $(0.74)$ & $(-5.15)$ & $(40.94)$ & $(1.55)$ \\
B & $0.70 \pm 0.01$ & $-4.85 \pm 0.14$ & $37.82 \pm 1.73$ & $1.28 \pm 0.10$ \\
& $(0.71)$ & $(-5.05)$ & $(38.50)$ & $(1.38)$ \\
\hline
\end{tabular}

Note: $V_{\mathrm{OC}}=$ open-circuit voltage, $J_{\mathrm{sC}}=$ short-circuit current, $\mathrm{FF}=$ fill factor, $\mathrm{PCE}=$ power conversion efficiency.

the presented results are consistent with previous results for solar cells with acceptor B fabricated with slightly different parameters. ${ }^{4 \mathrm{~b}}$

\section{Conclusions}

In conclusion, we prepared two TIPS-ethynylated phenazinothiadiazole dimers $\mathbf{3}$ and $\mathbf{4}$, covalently linked via nonconjugated alkylene bridges and compared them to related dimer $\mathbf{B}$ and their consanguine monomeric counterpart $\mathbf{6}$. Both $\mathbf{3}$ and $\mathbf{4}$ form amorphous thin films which, when employed as acceptors in BHJ solar cells, improve device performance compared to that of the crystalline monomer $\mathbf{6}$, as was the case for $\mathbf{B}^{4 \mathrm{~b}}$ Despite different intramolecular geometries (distance and relative orientation of chromophores), the dimers share similar optical and electrochemical properties -homoconjugation is vanishingly small in the phenazinothiadiazole dimers. This assumption is strengthened by comparing 3,4, and $\mathbf{B}$ in $\mathrm{BHJ}$ photovoltaic devices - we find that choice of linker has only minor influence with close to equal device performances. Despite the only moderate power conversion efficiencies (up to $1.6 \%$ ), our results provide valuable insight into the role of linker in homodimers. 


\section{Funding Information}

L.A. thanks the 'Studienstiftung des deutschen Volkes' for a scholarship. U. B. and Y. V. thank the Deutsche Forschungsgemeinschaft (SFB 1249) for generous support (Project A01 and (04).

\section{Supporting Information}

Supporting Information for this article is available online at https://doi.org/10.1055/s-0041-1726459.

\section{References And Notes}

(1) (a) Freudenberg, J.; Bunz, U. H. F. Acc. Chem. Res. 2019, 52, 1575. (b) Bunz, U. H. F. Acc. Chem. Res. 2015, 48, 1676.

(2) (a) Lakshminarayana, A. N.; Ong, A.; Chi, C. J. Mater. Chem. C Devices 2018, 6, 3551. (b) Miao, Q. Adv. Mater. 2014, 26, 5541. (c) Reiss, H.; Ji, L.; Han, J.; Koser, S.; Tverskoy, O.; Freudenberg, J.; Hinkel, F.; Moos, M.; Friedrich, A.; Krummenacher, I.; Lambert, C.; Braunschweig, H.; Dreuw, A.; Marder, T.; Bunz, U. H. F. Angew. Chem. Int. Ed. 2018, 57, 9543. (d) Chu, M.; Fan, J.-X.; Yang, S.; Liu, D.; Ng, C. F.; Dong, H.; Ren, A.-M.; Miao, Q. Adv. Mater. 2018, 30, 1803467.

(3) (a) Ganschow, M.; Koser, S.; Hahn, S.; Rominger, F.; Freudenberg, J.; Bunz, U. H. F. Chem. Eur. J. 2017, 23, 4415. (b) Hahn, S.; Koser, S.; Hodecker, M.; Seete, P.; Rominger, F.; Miljanić, O. ̌̌.; Dreuw, A.; Bunz, U. H. F. Chem. Eur. J. 2018, 24, 6968.

(4) (a) Leibold, D.; Lami, V.; Hofstetter, Y. J.; Becker-Koch, D.; Weu, A.; Biegger, P.; Paulus, F.; Bunz, U. H. F.; Hopkinson, P. E.; Bakulin, A. A.; Vaynzof, Y. Org. Electron. 2018, 57, 285. (b) Ahrens, L.; Butscher, J.; Brosius, V.; Rominger, F.; Freudenberg, J.; Vaynzof, Y.; Bunz, U. H. F. Chem. Eur. J. 2020, 26, 412. (c) Lami, V.; Leibold, D.; Fassl, P.; Hofstetter, Y.; Becker-Koch, D.; Biegger, P.; Paulus, F.; Hopkinson, P.; Adams, M.; Bunz, U. H. F.; Huettner, S.; Howard, I.; Bakulin, A.; Vaynzof, Y. Sol. RRL 2017, 1, 1700053. (d) Hahn, S.; Butscher, J.; An, Q.; Jocic, A.; Tverskoy, O.; Richter, M.; Feng, X.; Rominger, F.; Vaynzof, Y.; Bunz, U. H. F. Chem. Eur. J. 2019, 25, 7285.

(5) Ji, L.; Haehnel, M.; Krummenacher, I.; Biegger, P.; Geyer, F. L.; Tverskoy, O.; Schaffroth, M.; Han, J.; Dreuw, A.; Marder, T. B.; Bunz, U. H. F. Angew. Chem. Int. Ed. 2016, 55, 10498.

(6) Stolar, M.; Baumgartner, T. Phys. Chem. Chem. Phys. 2013, 15, 9007.

(7) Lim, Y.-F.; Shu, Y.; Parkin, S. R.; Anthony, J. E.; Malliaras, G. G. J. Mater. Chem. 2009, 19, 3049.

(8) Breuer, T.; Geiger, T.; Bettinger, H. F.; Witte, G. J. Phys.: Condens. Matter 2019, 31, 034003.

(9) Jang, J.; Nam, S.; Im, K.; Hur, J.; Cha, S. N.; Kim, J.; Son, H. B.; Suh, H.; Loth, M. A.; Anthony, J. E.; Park, J.-J.; Park, C. E. Adv. Funct. Mater. 2012, 22, 1005.

(10) Geyer, F. L.; Koser, S.; Bojanowski, M. N.; Ullrich, F.; Brosius, V.; Hahn, S.; Brödner, K.; Mankel, E.; Marszalek, T.; Pisula, W.; Hinkel, F.; Bunz, U. H. F. Chem. Commun. 2018, 54, 1045.

(11) Kumarasamy, E.; Sanders, S. N.; Tayebjee, M. J. Y.; Asadpoordarvish, A.; Hele, T. J. H.; Fuemmeler, E. G.; Pun, A. B.; Yablon, L. M.; Low, J. Z.; Paley, D. W.; Dean, J. C.; Choi, B.; Scholes, G. D.; Steigerwald, M. L.; Ananth, N.; McCamey, D. R.; Sfeir, M. Y.; Campos, L. M. J. Am. Chem. Soc. 2017, 139, 12488.
(12) (a) Budd, P. M.; Ghanem, B. S.; Makhseed, S.; McKeown, N. B.; Msayib, K. J.; Tattershall, C. E. Chem. Commun. 2004, 2, 230. (b) Carta, M.; Malpass-Evans, R.; Croad, M.; Rogan, Y.; Jansen, J. C.; Bernardo, P.; Bazzarelli, F.; McKeown, N. B. Science 2013, 339, 303. (c) Makhseed, S.; Samuel, J.; Bumajdad, A.; Hassan, M. J. Appl. Polym. Sci. 2008, 109, 2591. (d) Du, N.; Robertson, G. P.; Song, J.; Pinnau, I.; Thomas, S.; Guiver, M. D. Macromolecules 2008, 41, 9656. (e) McKeown, N. B. Polymer 2020, 202, 122736.

(13) Harig, M.; Neumann, B.; Stammler, H.-G.; Kuck, D. ChemPlusChem 2017, 82, 1078.

(14) Syntheses: $\mathbf{B},{ }^{4 \mathrm{~b}} \mathbf{1}^{22} \mathbf{5}^{23}$, and $\mathbf{6}^{4 \mathrm{~b}}$ were synthesized according to literature procedures. Precursor synthesis is elaborated on in the Supporting Information. CCDC 2055760 (1) and CCDC 2055761 (3) contain the supplementary crystallographic data for this paper. These data are provided free of charge by The Cambridge Crystallographic Data Centre via www.ccdc.cam.ac.uk/structures General procedure: In a heatgun-dried Schlenk tube under an atmosphere of argon was added ortho-diamine $\mathbf{5}$ (2.00 equiv), bisortho-quinone $\mathbf{1}$ or $\mathbf{2}$ and suspended in chloroform (50\% v/v) and acetic acid $(50 \% \mathrm{v} / \mathrm{v})$. The reaction mixture was stirred at $50{ }^{\circ} \mathrm{C}$ for $15 \mathrm{~h}$. The mixture was cooled to room temperature and diluted with water $(10 \mathrm{~mL})$. The phases were separated, and the aqueous layer was extracted with dichloromethane $(3 \times 10 \mathrm{~mL})$. The combined organic phases were washed with sodium bicarbonate solution $(10 \mathrm{~mL})$, dried over magnesium sulfate and filtrated. The solvent was removed under reduced pressure and the crude product was absorbed on Celite ${ }^{\circledR}$. After flash column chromatography (petroleum ether/diethyl ether 500:1 v/v $\rightarrow$ 250:1) and gel permeation chromatography (toluene), the condensation product $\mathbf{3}$ or $\mathbf{4}$ was isolated.

(15) 7,17-Dimethyl-4,10,14,20-tetrakis\{[triisopropylsilyl]ethynyl\}7H,17H-7,17-ethanobis[1,2,5]thiadiazolo[3,4-i:3,4-i']benzo[1,2$\left.b: 4,5-b^{\prime}\right]$ diphenazine (3): The general procedure was applied to bis-ortho-quinone $\mathbf{1}$ ( $10.0 \mathrm{mg}, 34.0 \mu \mathrm{mol}, 1.00$ equiv) and orthodiamine $\mathbf{5}$ (35.8 mg, $68.0 \mu \mathrm{mol}, 2.00$ equiv) in $500 \mu \mathrm{L}$ chloroform and $500 \mu \mathrm{L}$ acetic acid. Flash column chromatography $\left(\mathrm{SiO}_{2}\right.$; petroleum ether/diethyl ether $250: 1 \mathrm{v} / \mathrm{v} \rightarrow 100: 1 \rightarrow 50: 1)$ and gel permeation chromatography (toluene) yielded green solid 3 (33.3 mg, $26.1 \mu \mathrm{mol}, 77 \%)$. Mp: $340{ }^{\circ} \mathrm{C} ;{ }^{1} \mathbf{H ~ N M R}\left(\mathrm{CDCl}_{3}, 600 \mathrm{MHz}\right.$, $\mathrm{rt}): \delta=8.02(\mathrm{~s}, 4 \mathrm{H}), 2.26(\mathrm{~s}, 6 \mathrm{H}), 2.05(\mathrm{~s}, 4 \mathrm{H}), 1.31-1.36(\mathrm{~m}, 84 \mathrm{H})$ ppm; ${ }^{13} \mathbf{C}\left\{{ }^{1} \mathbf{H}\right\}$ NMR $\left(\mathrm{CDCl}_{3}, 151 \mathrm{MHz}, \mathrm{rt}\right): \delta=154.5,149.9,145.3$, 142.8, 121.5, 114.3, 111.5, 102.2, 42.2, 34.4, 29.8, 19.1, 11.8 ppm; IR(ATR): = 2941, 2862, 1454, 1455, 1417, 1365, 1195, 1127, 1027, 1016, 996, 921, 896, 881, 864, 740, 726, 666, $576 \mathrm{~cm}^{-1}$; HRMS $\left(\right.$ MALDI $\left.{ }^{+}\right) \mathrm{m} / z:[\mathrm{M}+\mathrm{H}]{ }^{+}$: calcd. for $\left[\mathrm{C}_{74} \mathrm{H}_{99} \mathrm{~N}_{8} \mathrm{~S}_{2} \mathrm{Si}_{4}\right]+$ : 1275.6506; found 1275.6522; correct isotope distribution.

(16) 4,4',12,12'-Tetrakis((triisopropylsilyl)ethynyl)-7H,7' $H, 9 H, 9^{\prime} H$ 8,8'-spirobi[cyclopenta[b][1,2,5]-thiadiazolo[3,4-i]phenazine] (4): The general procedure was applied to bis-ortho-quinone 2 (44.0 mg, $157 \mu \mathrm{mol}, 1.00$ equiv) and ortho-diamine 5 (165 mg, $314 \mu \mathrm{mol}, 2.00$ equiv) in $1.00 \mathrm{~mL}$ chloroform and $1.00 \mathrm{~mL}$ acetic acid. Flash column chromatography $\left(\mathrm{SiO}_{2}\right.$; petroleum ether/ diethyl ether $250: 1 \mathrm{v} / \mathrm{v} \rightarrow$ 100:1 $\rightarrow$ 50:1) and gel permeation chromatography (toluene) yielded green solid $\mathbf{3}$ (44.3 mg, 35.1 $\mu \mathrm{mol}, 22 \%)$. Mp: decomposition above $250{ }^{\circ} \mathrm{C} ;{ }^{1} \mathbf{H}$ NMR $\left(\mathrm{CDCl}_{3}\right.$, $600 \mathrm{MHz}, \mathrm{rt}): \delta=7.90(\mathrm{~s}, 4 \mathrm{H}), 3.29(\mathrm{~s}, 8 \mathrm{H}), 1.29-1.33(\mathrm{~m}, 84 \mathrm{H})$ ppm. ${ }^{13} \mathbf{C}\left\{{ }^{1} \mathbf{H}\right\}$ NMR $\left(\mathrm{CDCl}_{3}, 151 \mathrm{MHz}, \mathrm{rt}\right): \delta=154.7,150.4$, $146.0,142.7,124.6,114.4,111.3,102.4,53.2,44.8,19.2$, 11.9 ppm; IR (ATR): = 2940, 2863, 1456, 1416, 1366, 1018, 919, 880, 860, 733, 670, $572 \mathrm{~cm}^{-1}$; HRMS (MALDI ${ }^{+}$) $\mathrm{m} / \mathrm{z}$ : $[\mathrm{M}+\mathrm{H}]^{+}$: calcd. for $\left[\mathrm{C}_{73} \mathrm{H}_{97} \mathrm{~N}_{8} \mathrm{~S}_{2} \mathrm{Si}_{4}\right]^{+}: 1261.6349$; found 1261.6343; correct isotope distribution. 
(17) Baumgärtner, K.; Hoffmann, M.; Rominger, F.; Elbert, S. M.; Dreuw, A.; Mastalerz, M. J. Org. Chem. 2020, 85, 15256.

(18) Appleton, A. L.; Miao, S.; Brombosz, S. M.; Berger, N. J.; Barlow, S.; Marder, S. R.; Lawrence, B. M.; Hardcastle, K. I.; Bunz, U. H. F. Org. Lett. 2009, 11, 5222.

(19) Gaussian 16, Revision C.01, Frisch, M. J.; Trucks, G. W.; Schlegel, H. B.; Scuseria, G. E.; Robb, M. A.; Cheeseman, J. R.; Scalmani, G.; Barone, V.; Petersson, G. A.; Nakatsuji, H.; Li, X.; Caricato, M.; Marenich, A. V.; Bloino, J.; Janesko, B. G.; Gomperts, R.; Mennucci, B.; Hratchian, H. P.; Ortiz, J. V.; Izmaylov, A. F.; Sonnenberg, J. L.; Williams-Young, D.; Ding, F.; Lipparini, F.; Egidi, F.; Goings, J.; Peng, B.; Petrone, A.; Henderson, T.; Ranasinghe, D.; Zakrzewski, V. G.; Gao, J.; Rega, N.; Zheng, G.; Liang, W.; Hada, M.; Ehara, M.; Toyota, K.; Fukuda, R.; Hasegawa, J.; Ishida, M.; Nakajima, T.; Honda, Y.; Kitao, O.; Nakai, H.; Vreven, T.; Throssell, K.; Montgomery, J. A. Jr.; Peralta, J. E.; Ogliaro, F.; Bearpark, M. J.; Heyd, J. J.; Brothers, E. N.; Kudin, K. N.; Staroverov, V. N.; Keith, T. A.; Kobayashi, R.; Normand, J.; Raghavachari, K.; Rendell, A. P.; Burant, J. C.; Iyengar, S. S.; Tomasi, J.; Cossi, M.; Millam, J. M.; Klene, M.; Adamo, C.; Cammi, R.; Ochterski, J. W.; Martin, R. L.; Morokuma, K.; Farkas, O.; Foresman, J. B.; Fox, D. J. Gaussian, Inc.: Wallingford CT, 2016.

(20) Solar cell fabrication and characterization: Pre-patterned indium tin oxide (ITO) glass substrates were cleaned subsequently in acetone and isopropanol in a sonication bath for 5 min each, followed by a 10 min long oxygen plasma treatment. Immediately afterwards, a caesium-doped zinc oxide ( $\mathrm{ZnO}: \mathrm{Cs}$,
$2 \%$ molar ratio) solution was spin-cast onto the substrates following a previously reported procedure. ${ }^{24}$ The substrates were then transferred to a nitrogen glovebox. Here, the organic materials were dissolved separately in chlorobenzene at a concentration $10 \mathrm{mg} \mathrm{ml}^{-1}$ and then mixed in a $2: 3$ volume ratio of donor (PTB7) to acceptor (3, $\mathbf{4}$ or B). The mixed solutions were statically spin-cast on top of the ZnO:Cs layer at $800 \mathrm{rpm}$ for $55 \mathrm{~s}$, followed by $2000 \mathrm{rpm}$ for $5 \mathrm{~s}$. Lastly, $8 \mathrm{~nm}$ molybdenum trioxide $\left(\mathrm{MoO}_{3}\right)$ and $80 \mathrm{~nm} \mathrm{Ag}$ were thermally evaporated under high vacuum $\left(10^{-6} \mathrm{mbar}\right)$. External quantum efficiency (EQE) and current density-voltage $(J-V)$ characteristics of the completed devices were recorded with a source-measure unit (Keithley 2450) under ambient conditions. EQE was measured with the monochromated light of a halogen lamp calibrated with an NIST-traceable Si diode (Thorlabs), while JV curves were measured with simulated sun light from a Sun 3000 solar simulator (Abet technologies, class AAA) under AM 1.5 conditions.

(21) Cardona, C. M.; Li, W.; Kaifer, A. E.; Stockdale, D.; Bazan, G. C. Adv. Mater. 2011, 23, 2367.

(22) Ghanem, B. S.; McKeown, N. B.; Budd, P. M.; Fritsch, D. Macromolecules 2008, 41, 1640.

(23) An, C.; Zhou, S.; Baumgarten, M. Cryst. Growth Des. 2015, 15, 1934.

(24) (a) Hinzmann, C.; Magen, O.; Hofstetter, Y. J.; Hopkinson, P. E.; Tessler, N.; Vaynzof, Y. ACS Appl. Mater. Interfaces 2017, 9, 6220. (b) Sevinchan, Y.; Hopkinson, P. E.; Bakulin, A. A.; Herz, J.; Motzkus, M.; Vaynzof, Y. Adv. Mater. Interfaces 2016, 3, 1500616. 